\title{
THE SIGNIFICANCE OF NITROGEN MOBILIZATION WITH RESPECT TO THE DEVELOPMENT OF BARLEY
}

\author{
Yrjö Pessi and Mauri Takala \\ Society of Peat Cultivation Experimental Station, Leteensuo
}

Received July 8, 1959

Numerous factors affect the rate of development of plants, temperature being one of the most essential ones. The quantity in the soil of nitrogen utilizable by the plants also exerts an influence upon their time of growth. The present investigation carried out at the Experimental Station of Leteensuo, permits some conclusions to be drawn in regard to the significance of the said factors for the development of barley plants.

The procedure of investigation was to sow the test plants simultaneously on two growth sites differing distinctly with respect to nitrogen mobilization. The air and soil temperatures were measured on both sites and observations were made of the different stages of development of the plant, i.e. the shooting, the coming into ear, and the ripening. One of the growth sites had a tilled layer consisting of forest peat, in which the nitrogen mobilization is abundant enough to obviate the use of nitrogen fertilizer. The substrate on the other growth site was Sphagnum peat originating from $S$. fuscum moss, with a very slight nitrcgen mobilizaticn. The fertilization applied to fen soil consisted of $300 \mathrm{~kg}$ superphcsphate ard $150 \mathrm{~kg} 50 \%$ potassium chloride per hectare, while the peat bog received $200 \mathrm{~kg}$ Oulu saltpetre per hectare in addition. The barley was of the Pirkka variety. The method of air ard soil temperature measurements has been described in an earlier publication. ${ }^{1}$

Table 1. Stages of development of Pirkka barley on fen and Spahgnum bog soil at Leteensuo in the summer of 1958

\begin{tabular}{llllll}
\hline Soil type & Sown on & Shooting & $\begin{array}{l}\text { Coming } \\
\text { into ear }\end{array}$ & Ripening \\
\hline Fen & 11. VI & 17. VI & 26. VII & 15. IX \\
Sphagnum bog & 11.VI & 18 . VI & 28. VII & 8. IX \\
\hline
\end{tabular}

1 Pessi, Y. \& Takala, M. 1959. Some results of measurements at the Leteensuo Experimental Station relating to the temperatures of air and soil and to the humidity of air in the summer of 1958. Selostus: Eräitä ilman ja maan lämpötilaa sekä ilman kosteutta koeskevia mittaustuloksia Leteensuon koeasemalta kesällä 1958. Maat. tiet. aikak. 31:207-211. 
Table 2. Air temperature at the upper limit of the plant cover, and soil temperatures at 5 and $10 \mathrm{~cm}$ depth, on the growing sites of Pirkka barley

\begin{tabular}{|c|c|c|c|c|c|c|c|c|c|}
\hline \multirow[t]{3}{*}{ Soil type } & \multirow{2}{*}{\multicolumn{3}{|c|}{$\begin{array}{l}\text { Monthly mean of air } \\
\text { temperature }\end{array}$}} & \multicolumn{6}{|c|}{ Monthly mean of soil temperature } \\
\hline & & & & \multicolumn{3}{|c|}{$5 \mathrm{~cm}$ depth } & \multicolumn{3}{|c|}{$10 \mathrm{~cm}$ depth } \\
\hline & VI & VII & VIII & VI & VII & VIII & VI & VII & VIII \\
\hline Fen & 16,0 & 17,2 & 15,3 & 14,9 & 17,0 & 15,1 & 13,4 & 16,3 & 14,7 \\
\hline Sphagnum bog & 16,4 & 16,9 & 15,2 & 14,7 & 16,4 & 15,3 & 13,0 & 15,8 & 14,7 \\
\hline
\end{tabular}

The weather conditions in the summer of the investigation were characterized by the fact that every month of the growing period had a mean temperature about $1^{\circ} \mathrm{C}$ lower than normal. The mean temperature of the period May to September was $12.1^{\circ} \mathrm{C}$. The rainfall during the period May to September was $240 \mathrm{~mm}$.

Table 1 shows the different stages of development of the barley plants, and Table 2 the air and soil temperatures. It can be seen that up to the time of coming into ear the barley had developed at nearly the same rate on both growing sites, although its development had been slightly slower on the Sphagnum bog. However, the period of development from the coming into ear to the ripening was nine days shorter on the Sphagnum bog than on the fen site. It is evident from the temperature figures that the slower initial development of the barley plants was probably caused by the lower soil temperature. On the other hand the temperature of air as well as soil had been largely the same on both sites during the last period of development, i.e. the period from the coming into ear to the ripening. It appears likely, therefore, that the longer duration of this period on the fen site would account for the different mobilization of nitrogen. Since in the Sphagnum bog the nitrogen situation during the growing period is probably primarily such that the quantity of nitrogen utilizable by the plants at the beginning of the growing period is perhaps equivalent to that in fen soil, owing to the fertilization administered and to the low nitrogen mobilization, the nitrogen quantitity will become less as the plants use it up towards the autumn. In fen soil, on the other hand, the quantity of usable nitrogen can be assumed to increase owing to nitrogen mobilization, and this results in a delay in the ripening. The possible differences of soil moisture conditions between various peat types was probably not the cause of the difference at the time of ripening mentioned above, because e.g. in August it rained $47 \mathrm{~mm}$, so that the plant stands were not affected by dryness.

\section{$S u m m$ ary}

In the investigation has been stated, that up to time of coming into ear the barley had developed at nearly the same rate on the Sphagnum bog and the fen, which are differing distinctly with respect to nitrogen mobilization. However, the period development from the coming into ear to the ripening was nine days shorter on the Sphagnum bog than on the fen site. The temperature of air as well as soil had been largely the same on both sites during the period of development, from the coming into ear to the ripening. It appears likely, therefore, that the longer duration of this period on the fen site would account for the different mobilization of nitrogen. 
SELOST US:

\title{
TYPEN MOBILISAATION MERKITYKSESTÄ OHRAN KEHITYKSEEN
}

\author{
Yrjö Pessi ja Mauri Takala
}

Suoviljelysyhdistys, Leteensuon koeasema

Tutkimukset on suoritettu siten, että samanaikaisesti on koekasvi kylvetty kahdelle, typen mobilisaation puolesta erityisen selvästi toisistaan poikkeavalle kasvupaikalle. Lisäksi on mitattu ilman ja maan lämpötila molemmissa paikoissa sekä tehty havainnot kasvin eri kehitysasteista, nimittäin orastumisesta, tähkälletulosta ja tuleentumisesta. Toisen kasvupaikan muokkauskerros on ollut metsäsaraturvetta, jossa typen mobilisaatio on siksi runsasta, että typpilannoitusta ei tarvitse käyttää. Toisen kasvupaikan kasvualusta on ollut taas $S p$. fuscum-sammaleesta muodostunutta rahkaturvetta, jossa typen mobilisaatio on erittäin vähäinen. Lannoituksena annettiin mutasuolla $300 \mathrm{~kg}$ superfosfaattia ja $150 \mathrm{~kg} \mathrm{50- \% -kalisuolaa} \mathrm{hehtaarille.} \mathrm{Rahkasuolle} \mathrm{annettiin} \mathrm{näiden} \mathrm{lannoitteiden} \mathrm{lisăksi} 200 \mathrm{~kg}$ Oulunsalpietaria hehtaarille. Lajikkeena oli Pirkka-ohra. Ilman ja maan lämpötilan mittaustapa on selostettu aikaisemmin (ks. kirjallisuusviittaus s. 248).

Taulukossa 1 esitetään ohran eri kehitysvaiheet sekä taulukossa 2 ilman ja maan lämpötila. Niistä ilmenee, että ohra on kehittynyt tähkälletuloon saakka molemmissa kasvupaikoissa lähes yhtä nopeasti, joskin rahkasuolla hieman hitaammin. Kehitysvaihe tähkälletulosta tuleentumiseen on rahkasuolla ollut kuitenkin 9 päiväă lyhyempi kuin mutasuolla. Lämpötila-arvoista ilmenee, että ohran hitaampi alkukehitys rahkasuolla lienee johtunut maan alhaisemmasta lämpötilasta. Toisaalta sekä ilman että maan lämpötila on ollut viimeisen kehitysvaiheen aikana, siis tähkälletulon ja tuleentumisen vălillä, jokseenkin sama molemmissa kasvupaikoissa. Mainitun kehitysvaiheen muodostuminen mutasuolla 9 päivää pitemmäksi kuin rahkasuolla johtunee näin ollen typen mobilisaation erilaisuudesta kasvupaikkojen kesken. Kun typpitilanne rahkasuossa kasvukauden aikana lienee lähinnä sellainen, että kasveille käyttökelpoisen typen määrä on annetun lannoituksen ja vähäisen typen mobilisaation johdosta kasvukauden alussa ehkä mutasuon typpitilannetta vastaava, vähenee typen määrä syksyä kohti kasvien käyttäessä sitä. Sen sijaan mutasuossa typen mobilisaation ansiosta käyttökelpoisen typen määrä lisääntynee syksyä kohti, mistä on seurauksena tuleentumisen viivästyminen. Maan kosteusolojen mahdollinen eroavuus eri turvelajien kesken ei liene aiheuttanut mainittua eroa tuleentumisajankohdassa, sillä $\mathrm{mm}$. elokuussa satoi $47 \mathrm{~mm}$, eikä kuivuus vaivannut kasvustoja. 